\title{
THE CHANGING IDEA OF HIGHER EDUCATION
}

\author{
Vesna Holubek \\ ORCID iD 0000-0002-7737-0259 \\ M.Sc. (Admin.) \\ Researcher \\ Faculty of Education, University of Tampere \\ 4 Kalevantie Str., 33100 Tampere, Finland \\ Vesna.Holubek@uta.fi
}

\begin{abstract}
Questions concerning the purpose and the nature of higher education are often referred to as "the idea of higher education". The article illustrates that the idea of higher education is contextual and changeable, thus contested over time. The aim of the article is to present and analyse some of the most prominent changes in the idea of higher education last three decades by reviewing relevant literature. The analysis focuses on three major influences that redefine the idea of higher education in Europemassification, globalisation and internationalisation, and neoliberal ideas. The recognised changestransform the way highereducation is understood and conceptualised which in turn affects the way higher education is organised and developed in practice.

Key words: change; Europe; globalisation; higher education; idea; internationalisation; massification; neoliberalism; university
\end{abstract}

\section{INTRODUCTION}

Questions concerning the purpose and the nature of higher education have been contested over time. Historically, there have been various conceptualisations of the idea of higher education; this discussion continues today and remains inconclusive (Barnett, 1990; Rothblatt, 2009). Phrase "the idea of higher education" is often used to indicate discussion about the foundations upon which the higher education practice and system are built upon. Thus, when talking about the "idea of higher education" one usually refers to questions concerning the purpose and the nature of higher education (Rothblatt, 2009). Following a thorough analysis of the idea of higher education by Rothblatt (2009) the idea of higher education, as understood in this article, integrates two concepts: (1) the essence of higher education (definition of higher education - what is it?), and (2) the purpose of higher education (including synonyms "mission" and "function"; description of its activities - what is it for?).

The article aims to present and analyse some of the most prominent changes in the idea of higher education last three decades. The focus will be on higher education in the context of European continent. The analysis includes review of relevant literature that deals with idea of higher education. The recognized changes have significantly transformed the way higher education is understood and conceptualised which in turn affects the way it is organised and developed in practice.

The article illustrates that the idea of higher education is contextual and changeable, thus contested over time. Therefore, it is essential that the discussion about the idea of higher education is raised, and dominant understandings are re- 
examined anew. Higher education community needs to reflect on the compass that directs and defines guiding principles behind higher education activities. Public and academic debate over higher education must go beyond topics such as size or the cost of higher education system and seriously reflect the idea and nature of higher education (Barnett, 1990).

\section{THE IDEA OF HIGHER EDUCATION}

Analysing the history of the debate about "the idea of university", Rothblatt (2009) provides a good illustration of the questions posed: "For the sake of argument we might say that the idea of a university is education, but what kind should it be? Liberal, vocational, technical, research-related? Is the object culture, citizenship, leadership or career? Are the recipients young men, young men and women, 'mature' students, postgraduates? Do they attend full or part time? The idea of a university can be negative. A university is not the place for this or that purpose because it is the place for something else." (Rothblatt, 2009, p. 179).

Similarly, Bergan (2006) explores the main purposes of learning in the context of European countries and argues that the purpose of higher education changes over time on both, individual participant level, as well as for education as a whole. Discourse and understanding of the purpose of higher education are being reformed by the new developments in society. According to Bergan (2006), purposes of higher education can be grouped in 4 categories: (1) Preparation for the labour market; (2) Preparation for life as active citizens in democratic societies; (3) Personal development; and (4) Development and maintenance of a broad, advanced knowledge base. All four purposes are equally important and should complement each other; however, it is evident that these 4 purposes can be put in a hierarchy - from the most debated purpose (1. preparation for the labour market) to the least prominent one (4. development and maintenance of a broad, advanced knowledge base) (Bergan, 2006).

Therefore, as previously stated, the idea of higher education is changeable over time. In addition, broader historical context greatly influences the way higher education is understood, as well as practised. Broader historical context for higher education systems in Europe can be illustrated through three dominant models of higher education: British liberal-arts tradition, German Humboldtian model and occupation-oriented French system (Jonsson, 2006; Rothblatt, 2009). Numerous authors agree that these are the three dominant models of higher education in Europe. However, Jonsson (2006) argues that we should not forget the old Soviet system that also developed specific model in which universities were responsible only for teaching while research took place in academies of science.

One of the first authors who addressed specifically the "idea" of university education is cardinal and Oxford academic, John Henry Newman. In his work "The idea of a University: Defined and illustrated" that was first published in 1852, Newman describes his idea of higher education and principles that should lead higher education activities. According to Newman, university is a place of teaching universal knowledge and its primary purpose is intellectual and pedagogical, not moral or religious (Newman, \& Turner, 1996). Newman defines higher education as liberal education. Being one of the pioneers in academic discussion on the idea of higher education, Newman's importance in theory of higher education is immense, even though his works have had the greatest influence on British education: "It 
was Newman who transformed the inherited legalistic description of a university as a corporate body possessing endowments and privileges pertaining to learning into a thrilling emotion-laden, higher order conception of education." (Rothblatt, 2009, p. 183).

Most of northern, central and eastern Europe was on the other hand largely influenced by the German ideas of higher education developed in the 19th century. German higher education model, also known as Humboldtian model, was elaborated through the work of Wilhelm von Humboldt, a Prussian philosopher and founder of University of Berlin. Humboldtian model considers the universities to be "the home of the highest and best form of scholarship and science" (Rothblatt, 2009, p. 195). This institution, as a research university, should have a holistic combination of teaching and research. The primary duty of professors is research, while through teaching activities they communicate the results of their research to their students: "Above all, they [professors] should by word and deed make clear to them [students] that scientific and scholarly work is a never-ending activity, is ruled by nothing else than the reason of man, the fruits of which should be available to everyone" (Jonsson, 2006, p. 56). Students' personal formation, i.e. "Bildung" in German, is the main purpose of higher education, according to Humboldtian model. Bildung refers to a process of self-formation through internal freedom, autonomy and harmony. Academic freedom is another important feature of Humboldtian model - professors choose the content of their research and teaching according to their interest, and students are free to study what they want (Jonsson, 2006). As Krull (2006, p. 145-146) summarizes it, Humboldt's idea of a modern university rested on four principles: (1) the integration of teaching and research; (2) the complementary principles of freedom to teach and freedom to study; (3) the demand for solitude and freedom in the autonomous pursuit of truth; and (4) the introduction of the seminar system as the backbone of a community of lecturers and students. Most of higher education systems in Europe were greatly influenced by Humboldtian higher education idea.

Interestingly, in the higher education literature phrases "the idea of higher education" and "the idea of university" are used interchangeably. University, being a place of higher learning, is often seen as synonym for higher education. However, it is important to note that university is an institution through which higher education has been traditionally provided, but in the last two decades higher education happens also outside of the university. Alternative sources of knowledge acquisition are being developed (e.g. internet and communication technologies) that drastically change the processes of teaching and learning (e.g. distance learning). In this context, alternative research providers gain greater influence on knowledge production and dissemination (e.g. think tanks, research institutes, corporate research) (Smith, \& Webster, 1997b). These changes support the speculations about "the decline, even the death, of the university as an institution" (Smith, \& Webster, 1997b, p. 106). University's loss of monopoly over knowledge paired with technological and communication advancements opens the possibilities of learning, even gaining higher education without university (Bauman, 1997; Brown, \& Scase, 1997). Today, university is turning into a merely accrediting institution (Kumar, 1997; Smith, \& Webster, 1997a). Thus, the context in which higher education takes place has changed and it is important to differentiate higher education and university, and accordingly, differentiate the idea of higher education and the idea of university. 


\section{RECENT CHANGES IN UNDERSTANDING HIGHER EDUCATION}

Over time, every education system changes influenced by fluctuations in society that are conveyed through state policies, international organisations as well as education system actors themselves: "the inner logic of universities is under pressure from governments, the public, the students themselves" (Ashby, 2009 , p. 251). Various understandings of higher education are closely related to societal interests, i.e. shifting ideologies shift the idea of higher education in a particular time and place (Barnett, 1990). Thus, the previously mentioned higher education models dominant in Europe have undergone many changes in the last three decades. Nybom (2006, p. 4) claims that higher education institutions "are no longer considered to be responsible and invaluable academic and national cultural centres". The ultimate mission of higher education institutions is being questioned and redefined, and universities are, due to the high level of politicization of higher education and research, today seen as "instrumental means to hide unemployment among young people" (Nybom, 2006, p. 4). Some authors claim that modern university is changing too slowly for the contemporary, i.e. postmodern society (Bauman, 1997; Kerr, 2009a) and that "postmodern troubles cannot be adequately handled by modern means" (Bauman, 1997, p. 24). Barnett (2000, p. 6) identifies the current time as "the age of supercomplexity" - when the fundamental frameworks for understanding the world are endlessly multiplying and are often in conflict. Similarly, Kerr (2009a) asserts that the historical tendency has been for university functions to expand and become more complex leading to competing visions of true purpose of university. Characterised by complexity, today's modern university is a "Multiversity": "The university is so many things to so many different people that it must, of necessity, be partially at war with itself." (Kerr, 2009b, p. 309).

Aiming to trace some of the major changes in higher education sector in Europe, this article will analyse influences of massification, globalisation and internationalisation processes and neoliberal ideas.

\section{MASSIFICATION}

Quantitative expansion of higher education systems inevitably affects the way that higher education is organised. Already in 1973, Martin Trow has predicted some of the changes that massification of higher education will bring. He argues that there is a pattern in growth of higher education that manifests through three phases: elite, mass and universal higher education systems (Trow, 1973). According to Trow (1973), higher education system enters the mass phase when the participation reaches 15 percent of the age group, and when the participation exceeds 50 percent, the system is considered to be universal. Three phases of transition that Trow proposes are Weberian ideal types; nonetheless, the analysis and patterns of changes that Trow recognised gives us valuable insight into the processes behind massification of higher education.

Transition between the three phases reforms the higher education in a fundamental way and changes the very idea of higher education. In elite phase the purpose of higher education is to shape "the mind and character of the ruling class" (Trow, 1973, p.7) while in the mass phase the purpose shifts toward developing professional and technical skills. Higher education in the universal phase is about 
preparing for life in a society characterised by social and technological change (Trow, 1973, p. 7-8).

Trow has identified numerous aspects of transition that are visible in higher education system. Access to higher education is seen as a privilege in the elite phase, but becomes a right in the mass phase and, moreover, an obligation in universal phase. Accordingly, the curriculum and forms of instruction change from highly structured and specialised in the elite phase to more flexible modular curriculum in the mass phase and to increasingly unstructured instruction with loose boundaries of courses and weakened distinction between learning and life in the universal phase. The form of instruction and relationship between teacher and student also change - as the number of students grows and lecture halls become larger, the instruction is more formalized and increasingly mediated by technology. Transition toward universal system also results with more heterogeneous student population and increased importance of lifelong learning.

Larger student population also transforms higher education institutions they become more diversified and open to society with participatory forms of governance, and less campus-situated. As larger portion of population becomes involved in higher education, the system gains more stakeholders and stakeholder groups and there is a need for regulated quality assurance.

The expansion in higher education has been significant over recent decades and on average across OECD countries, 42 percent of 25-34 year-olds are tertiary educated (OECD, 2016). According to Trow's classification, 42 percent of highly educated population indicates mass higher education system that is fast-approaching to become universal. Higher education in the context of larger student population is organised differently but also understood differently. Trow's analysis from 1973 illustrates how fundamentally system changes when undergoing expansion.

\section{GLOBALISATION AND INTERNATIONALISATION}

Globalisation and internationalisation are forces that shape the very nature of higher education, its purpose and the way it operates. A noticeable increase of research analysing various aspects of internationalisation in higher education since mid-1990s indicates that this has become one of the major research topics that intrigues numerous scholars (Kehm, \& Teichler, 2007). Although greatly discussed, terms globalisation and internationalisation have been differently interpreted and defined by different authors and in different times. Due to their complexity, multidimensionality and susceptibility to change over time, the conceptualisation of these phenomena have resulted with variety of perspectives.

Terms globalisation and internationalisation in higher education area are often used interchangeably although there is a significant difference as well as overlapping between them. According to Altbach and Knight (2007) globalisation refers to the context in which higher education changes, specifically economic, political and societal forces that push higher education in 21st century toward internationalisation. Internationalisation includes responses to globalisation in form of policies and practices undertaken by higher education systems and institutions to cope with the globalised academic environment (Altbach, \& Knight, 2007). Therefore, internationalisation of higher education can be defined as "the process of integrating an international, intercultural, and global dimension 
into the purpose, functions (teaching, research, and service), and delivery of higher education at the institutional and national levels" (Knight, 2008, p. 12). According to Knight (2012), internationalisation activities can be grouped as internationalisation at home (refers to international scholars and students, international research activities, internationalisation in curriculum etc.) and internationalisation abroad (includes mobility of students, scholars, programmes, institutions etc.). Internationalisation abroad is often used interchangeably with terms "transnational" or "cross-border" education.

Aiming to provide the most relevant education to students - future citizens, entrepreneurs and scientists, internationalisation has many benefits for higher education systems (Hénard, Diamond, \& Roseveare, 2012). It can instigate strategic thinking leading to innovation, stimulate new learning and teaching methods, and create new research collaborations. Internationalisation as a part of higher education culture can invoke a greater awareness of the global issues and of differences in the way educational systems operate across countries, cultures and languages (Hénard et al., 2012).

Relevant scholars who explored globalisation trends and internationalisation responses emphasise, on the other hand, that there has been a shift in understanding and defining these phenomena in higher education (Kehm, \& Teichler, 2007; Knight, 2004; Teichler, 2004; van der Wende, 2007). This shift also transforms the way internationalisation in higher education is being studied, understood, and practically dealt with. The basic idea of the shift is that the internationalisation moved from being an added value to higher education institutions' core activities to being the centre of strategic planning, branding and policy-making. Internationalisation in higher education has come a long way from periphery to the very centre of higher education community interest (Teichler, 2004; Brandenburg, \& de Wit, 2011). Teichler (2004) describes the shift in internationalisation focus arguing that marketization, competition and management are being more and more important in higher education sector. He describes qualitative leaps that occurred in internationalisation of higher education: (1) "international" is not reserved just for the very few anymore, it became a necessity; (2) international activities became systematised and embedded in higher education institutions present in all arenas of decision-making and administration; (3) international education touches all areas of study and research to a certain extent (Teichler, 2004). In a similar fashion, Brandenburg and de Wit (2011, p. 16) declare "the end of internationalisation" in the late 1970s up to the mid-1980s, internationalisation meant a simple student exchange; it was not planned nor perceived as institutional prestige. Today, internationalisation is strategically planned and often present in the universities' mission statement. It is a recruitment business greatly influenced by international rankings. This shift has changed the very nature of internationalisation "from substance to form" (Brandenburg, \& de Wit, 2011, p. 16). Thus from being a mean to an end, internationalisation turned into an end for itself becoming "a catchall phrase losing its meaning and direction" (Knight, 2011, p. 14).

Furthermore, internationalisation has been usually seen as something good as opposed to globalisation that was branded as bad. With the dawn of rivalling term globalisation - internationalisation has gained its moral ground and, at the same time, lost its essence. Brandenburg and de Wit (2011) express their concern that this "constructed antagonism" devalues internationalisation and blurs the crucial issue - what is the nature and the mission of higher education in the present time. 
Internationalisation is gaining greater importance in higher education on national, institutional and individual level. And inevitably, international dimension is becoming an integral part of the idea of higher education.

\section{NEOLIBERAL IDEAS}

Olssen and Peters (2005) claim that OECD countries are going through a "neoliberal revolution" over the last three decades. Moreover, some authors assert that the neoliberal perspective has become so dominant in contemporary society that all policy-making processes are ultimately neoliberal by their nature (Harris, 2007).

Neoliberalism can be broadly defined as: "a theory of political economic practices that proposes that human well-being can best be advanced by liberating individual entrepreneurial freedoms and skills within an institutional framework characterised by strong private property rights, free markets and free trade" (Harvey, 2005, p. 2). Thus, the basic feature of neoliberal thinking is that individual freedoms are guaranteed by freedom of the market and of trade.

The rise of the neoliberal theory can be traced back to the foundation of Mont Pelerin Society in mid-20th century that gathered economists, historians and philosophers, including Friedrich Hayek, Karl Popper, and Milton Friedman (Harvey, 2005; Olssen \& Peters, 2005). The Mont Pelerin Society expressed their commitment to the ideals of personal freedom and advocated for the free market principles as opposed to interventionist state. Neoliberal theory gained its academic respectability (especially in University of Chicago where Milton Friedman taught) as well its practical application, visible in national policies adopted in 1980s in USA and UK.

According to neoliberal theory, the role of state is to guarantee proper functioning of market, and in the areas in which the market does not exist (such as health, education, water and land) they must be created, by state intervention if necessary (Harvey, 2005). Thus governance that is led by neoliberal ideas is characterised by marketization, withdrawal of the state from many areas of social provision, privatisation and competition; and the main objective of the neoliberal reforms is to increase productivity, accountability and control (Harvey, 2005; Olssen, \& Peters, 2005).

The most influential neoliberal reform in higher education is the New Public Management (NPM). Using the United States of America as a model, NPM has been very influential since the early 1990s in the reforms of the public higher education sector in Europe (Sporn, 2003). Aiming to cut the state costs in higher education, many European countries introduced NPM and restructured the public sector. In the NPM reforms, withdrawal of the state means greater institutional autonomy as well as greater inter-institutional competition. Moreover, introduction of higher education quasi-market makes higher education institutions more competitive, entrepreneurial and market-oriented, and the system more efficient and effective (Sporn, 2003).

Thus, the idea of higher education in the context of neoliberal reforms is connected to the processes such as marketization, privatisation, corporatisation, competition, efficiency, productivity, accountability and control. Many authors criticise this neoliberal direction of higher education policies claiming that it goes against the idea of the public university "as a place where ideas are pursued as ends 
in themselves; a place where, even if unpopular, such ideas are to be exempt from censorship, partisan politics, and the demands of corporate sponsors or donors" (Côté \& Allahar, 2011, p. 17). Neoliberalism transforms social relations into calculable units than are exchangeable on the market; ultimately, neoliberalism commodificates educational practice (Ball, 2012).

Strengthening the connection between education and work life on one side, and on another, between education and market, is one of the leading drivers of educational reform internationally (Apple, 2006). Within the neoliberal discourse, education fails to provide workers with appropriate skills and the solution that neoliberalism proposes is to apply market logic to educational system (Apple, 2006; Gandin, 2006). As Ball (2015, p. 825) puts it, "living the life of a neoliberal academic" in a "neoliberal university" changes "what it means to teach and research in higher education".

It is visible that neoliberal discourse develops new societal expectations from higher education systems: they are to contribute to economic goals of countries. Higher education sector is seen as an economic actor that should be led by the market rules. Thus, there is a demand for (re)defining the higher education processes in order to serve the market needs. For example, quality assurance system should ensure that education provided is relevant primarily for the labour market needs. Similarly, research is to feed into business development and internationalisation is to contribute to international competitiveness. Ball speaks about neoliberalism being about "both money and minds" (Ball, 2012, p. 3) which leads to the rise of "neoliberal university" (Ball, 2015, p. 825).

\section{CONCLUDING REMARKS}

The article focused on three major influences that redefine the idea of higher education in Europe - massification, globalisation and internationalisation and neoliberal ideas. It is important to note that these three influences are intertwined processes and closely related to other influences that redefine the way higher education is understood and organised. Thus, the influence of postmodernism in 1980s is noteworthy. Postmodern discourse introduced the idea of alternative knowledge and problematized the knowledge-production actors and processes (Lyotard, 1984). Related to this, the influence of information technologies and rise of alternative knowledge producers redefines both teaching and research functions of higher education. In addition, information technologies introduce new ways of communication as well as new ways of teaching, learning and researching.

Strong forces of internationalisation in the context of European higher education are also Bologna process and European Union policies. These forces transform the higher education sector in European countries and redefine the idea of higher education. In that sense, a "drift toward vocationalism" can be (also) observed in the European higher education (Côté, \& Allahar, 2011, p. 14). By analysing the Canadian higher education, Côté and Allahar (2011) recognise that higher education today insists on training rather than education. According to Côté and Allahar (2011), education is more general and aims to develop an open-minded and civic-minded citizenry, while training is about specialization and development of specific range of skills: "We argue that while one may be trained in engineering, one can only be educated in the liberal arts and sciences: education and training are not inimical to one another; they merely speak to different moments in the 
complex process of teaching, learning, and sharing information." (Côté, \& Allahar, 2011, p. 15).

Additionally, numerous other trends can be recognized in higher education in Europe such as diversification of higher education institutions that accompanied expansion, more heterogeneous student population, diversification of funding sources and new funding schemes, new forms of institutional governance, growing emphasis on accountability and performance and development of formal quality assurance systems.

Referring to the concept of "Multiversity" and its external and internal complexities, Jonsson (2006, p. 59) questions whether it is possible to talk about universities as coherent bodies with an identity of their own, or about "the idea of a university". Smith and Webster (1997a) express the same doubt by stating that today's universities are so diverse, fractured and differentiated that it may have become absurd to seek for any common organising principle, a common "idea" of higher education. Paradoxically, the common feature of the university in postmodern moment, namely a "postmodern university" is the "multiplicity of differences" as Smith and Webster (1997b, p.104) name it. These authors imply, and we would agree, that we should not think about a single "idea" of a higher education. Rather we must go beyond the traditional purposes of higher education (teaching, research and service to society), consider the plurality of thinking about the higher education and try to identify multiple "ideas of higher education".

\section{REFERENCES}

Altbach, P., G. \& Knight, J. (2007). The Internationalization of Higher Education: Motivations and Realities. Journal of Studies in International Education, 11(3-4), 290-305. doi: 10.1177/1028315307303542

Ashby, E. (2009). Idea of a university. In Lowe, R. (Ed.), The History of Higher Education: Major Themes in Education, Vol. 2, 241-252. Abingdon, UK: Routledge.

Apple, M. W. (2006). Understanding and Interrupting Neoliberalism and Neoconservatism in Education. Pedagogies: An International Journal, 1(1), 2126. doi: 10.1207/s15544818ped0101_4

Ball, S. J. (2012). Global Education Inc.: New Policy Networks and the Neoliberal Imaginary. New York, US: Routledge.

Ball, S. J. (2015). Accounting for a sociological life: influences and experiences on the road from welfarism to neoliberalism. British Journal of Sociology of Education, 36(6), 817-831. doi: 10.1080/01425692.2015.1050087

Barnett, R. (1990). The Idea of Higher Education. Buckingham, UK: Open University Press.

Barnett, R. (2000). Realizing the University in an age of supercomplexity. Buckingham, UK: Open University Press.

Bauman, Z. (1997). Universities: Old, New and Different. In A. Smith and F. Webster (Eds.), The Postmodern University?: Contested Visions of Higher Education in Society, 17-26. Buckingham, UK: Open University Press.

Bergan, S. (2006). Promoting New Approaches to Learning. In E. Froment, J. Kohler, L. Purser, \& L. Wilson (Eds.), EUA Bologna Handbook: Making Bologna Work, (Vol 4), (B 1.1-1). Berlin, Germany: Raabe. 
Bienefeld, S., \& Almqvist, J. (2004). Student Life and the Roles of Students in Europe. European Journal of Education, 39(4), 429-441. doi: 10.1111/j.1465-3435.2004.00195.x

Brandenburg, U. \& de Wit, H. (2011). The End of Internationalization. International Higher Education, 62(1), 15-17. doi: https://doi.org/10.6017/ ihe.2011.62.8533

Brown, P., \& Scase, R. (1997). Universities and Employers: Rhetoric and Reality. In A. Smith and F. Webster (Eds.), The Postmodern University?: Contested Visions of Higher Education in Society, 85-98. Buckingham, UK: Open University Press.

Côté, J. E., \& Allahar, A. L. (2011). Lowering higher education: The rise of corporate universities and the fall of liberal education. Toronto [Ont.], Canada: University of Toronto Press.

Gandin, L. A. (2006). Creating Real Alternatives to Neoliberal Policies in Education: The Citizen School Project. In M. W. Apple \& K. L. Buras (Eds.), The Subaltern Speak: Curriculum, Power, and Educational Struggles (pp. 217241). New York, US: Routledge.

Harris, S. (2007). The Governance of Education: How neo-liberalism is transforming policy and practice. London, UK: Bloomsbury Academic.

Harvey, D. (2005). Brief History of Neoliberalism. Oxford, UK: Oxford University Press.

Hénard, F., Diamond, L., \& Roseveare, D. (2012). Approaches to Internationalisation and Their Implications for Strategic Management and Institutional Practice: A Guide for Higher Education Institutions. OECD Publishing.

Jonsson, I. (2006). Universities, Research and Politics in Historical perspective. In K. Blückert, G. Neave, \& T. Nybom (Eds.), The European Research University: An Historical Parenthesis, (51-60). New York, US: Palgrave Macmillan.

Kehm, B. M. \& Teichler, U. (2007). Research on Internationalisation in Higher Education. Journal of Studies in International Education, 11(3-4), 260-273. doi: $10.1177 / 1028315307303534$

Kerr, C. (2009a). Functions - the pluralistic university in the pluralistic society. In R. Lowe (Ed.), The History of Higher Education: Major Themes in Education, Vol. 2, 286-305. Abingdon: Routledge.

Kerr, C. (2009b). The idea of a multiversity. In Lowe, R. (Ed.), The History of Higher Education: Major Themes in Education, Vol. 2, (306-328). Abingdon, UK: Routledge.

Knight, J. (2004). Internationalization Remodeled: Definition, Approaches, and Rationales. Journal of Studies in International Education, 8(1), 5-31. doi: $10.1177 / 1028315303260832$

Knight, J. (2008). Higher Education in Turmoil: The Changing World of Internationalization. Rotterdam: Sense Publishers.

Knight, J. (2011). Five Myths About Internationalization. International Higher Education, 62(1), 14-15. doi: https://doi.org/10.6017/ihe.2011.62.8532

Knight, J. (2012). Internationalization: Three Generations of Cross-border Higher Education. New Delhi, India: India International Centre. Retrieved from http://www.iicdelhi.nic.in/ContentAttachments/Publications/ DiaryFiles/53511July92012_IIC Occasional Publication 38.pdf

Krull, W. (2006). Coping with Change is not Enough for Universities. In K. Blückert, G. Neave \& T. Nybom (Eds.), The European Research University: An Historical Parenthesis, 51-60). New York, US: Palgrave Macmillan. 
Kumar, K. (1997). The Need for Place. In A. Smith \& F. Webster (Eds.), The Postmodern University?: Contested Visions of Higher Education in Society, 27-35. Buckingham, UK: Open University Press.

Lyotard, J. (1984). The postmodern condition: A report on knowledge. Manchester, UK: Manchester University Press.

Newman, J. H., \& Turner, F. M. (1996). The Idea of a University. New Haven: Yale University Press.

Nybom, T. (2006). Creative Intellectual Destruction or Destructive Political Creativity? Critical Reflections on the Future of European "Knowledge Production”. In K. Blückert, G. Neave \& T. Nybom (Eds.), The European Research University: An Historical Parenthesis, 3-13. New York, US: Palgrave Macmillan.

OECD. (2016). Education at a Glance 2016: OECD Indicators. Paris, France: OECD Publishing. Retrieved from http://dx.doi.org/10.1787/eag-2016-en

Olssen, M., \& Peters, M. A. (2005). Neoliberalism, higher education and the knowledge economy: from the free market to knowledge capitalism. Journal of Education Policy, 20(3), 313-345. Retrieved from http://dx.doi. org/10.1080/02680930500108718

Rothblatt, S. (2009). The idea of the idea of a university and its antithesis. In R. Lowe (Ed.), The History of Higher Education: Major Themes in Education, Vol. 2, 178-221. Abingdon, UK: Routledge.

Smith, A., and Webster, F. (1997a). Changing Ideas of the University. In A. Smith and F. Webster (Eds.), The Postmodern University?: Contested Visions of Higher Education in Society, 1-14. Buckingham, UK: Open University Press.

Smith, A., \& Webster, F. (1997b). Conclusion: An Affirming Flame. In A. Smith and F. Webster (Eds.), The Postmodern University?: Contested Visions of Higher Education in Society, (99-113). Buckingham, UK: Open University Press.

Sporn, B. (2003). Convergence of Divergence in International Higher Education Policy: Lessons from Europe. Publications from the Forum for the Future of Higher Education, 29-52. Retrieved from https://net.educause.edu/ir/library/ pdf/ffp0312s.pdf

Teichler, U. (2004). The Changing Debate on Internationalisation of Higher Education. Higher Education, 48(1), 5-26. Retrieved from http://www.jstor. org/stable/4151528

Trow, M. (1973). Problems in the transition from elite to mass higher education. California, US: Carnegie Commission on Higher Education.

van der Wende, M. (2007). Internationalization of Higher Education in the OECD Countries: Challenges and Opportunities for the Coming Decade. Journal of Studies in International Education, 11(3-4), 274-289. doi: $10.1177 / 1028315307303543$ 